Document downloaded from:

http://hdl.handle.net/10251/78747

This paper must be cited as:

Miró Richart, P.; Lhiaubet, VL.; Marín García, ML.; Miranda Alonso, MÁ. (2015).

Photosensitized Thymine Dimerization via Delocalized Triplet Excited States. Chemistry - A European Journal. 21(47):17051-17056. doi:10.1002/chem.201502719.

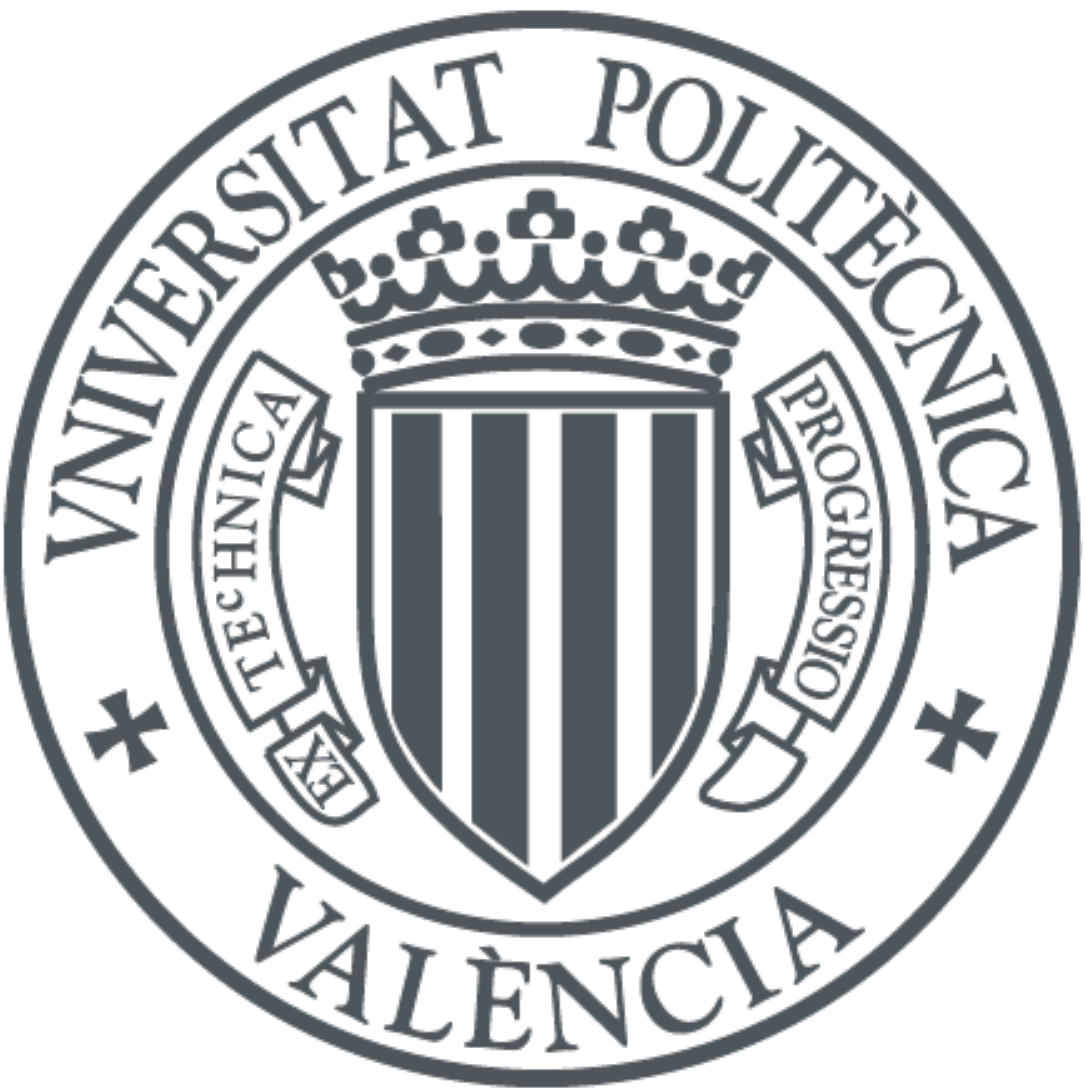

The final publication is available at

http://doi.org/10.1002/chem.201502719

Copyright Wiley

Additional Information 


\section{Photosensitized Thymine Dimerization via Delocalized Triplet Excited States}

\author{
Paula Miro, ${ }^{\text {[a] }}$ Virginie Lhiaubet-Vallet, ${ }^{[a]} M$. \\ Luisa Marin*,[a] and Miguel A. Miranda*,[a]
}

\begin{abstract}
A new mechanism of photosensitized formation of thymine (Thy) dimers is proposed, which involves generation of a delocalized triplet excited state as the key step. This is supported by chemical evidence obtained by combining one benzophenone and two Thy units with different degrees of freedom, where the photoreactivity is switched from a clean Paternò-Büchi to a fully chemo-, regio- and stereoselective [2+2] cycloaddition.
\end{abstract}

\section{Introduction}

Ultraviolet solar radiation reaching the Earth surface has been widely reported as a potential mutagenic agent. ${ }^{[1]}$ Nucleobases are able to absorb UVB light, causing direct photoreactions from their singlet excited states such as formation of cyclobutane thymine dimers (Thy<>Thy) or (6-4) photoproducts that are among the most mutagenic alterations. ${ }^{[2]}$ Nanosecond IR spectroscopy has revealed that intrinsically populated Thy triplets decay in DNA single strands via formation of biradical intermediates that can end in cyclobutane dimers, although they predominantly decay through non-reactive pathways. ${ }^{[3]}$ Although solar UVA light is less efficiently absorbed by the nucleobases, the presence of endogenous or exogenous photosensitizers that can be excited in that region, may greatly enhance UVA-mediated photochemical disorders. Moreover, theoretical CASPT2//CASSCF calculations on the photosensitized process indicate formation of a stabilized triplet excimer from a parallel stacked triplet pair of nucleobases. ${ }^{[4]}$

In this context, benzophenone (BP) and drugs containing the BP chromophore have been widely reported as DNA photosensitizers. ${ }^{[5]}$ It is assumed that BP-photosensitized DNA damage includes triplet-triplet energy transfer (TTET) from ${ }^{3} \mathrm{BP}^{*}$ to Thy, followed by $[2+2]$ cycloaddition yielding Thy<> Thy. ${ }^{[5-6]}$

[a] Instituto Universitario Mixto de Tecnología Química (UPV-CSIC) Universitat Politècnica de València

Avenida de los Naranjos s/n, 46022 Valencia, Spain

E-mail: mmiranda@qim.upv.es; marmarin@qim.upv.es

Supporting information for this article is given via a link at the end of the document.

Formation of these dimers occurs along with the Paternò-Büchi reaction between ${ }^{3} \mathrm{BP}^{*}$ and Thy resulting in the formation of oxetanes, which have been claimed as models to mimic the highly unstable intermediates involved in the repair of (6-4) photoproducts. ${ }^{[5 b, 7]}$

The rate constant for TTET should be related to the energy gap between ${ }^{3} \mathrm{BP}^{*}$ and ${ }^{3}$ Thy ${ }^{*}{ }^{[8]}$ Although it seems a slightly disfavored process in solution (triplet energies of 70 and $74 \mathrm{kcal} \mathrm{mol}^{-1}$ for BP and Thy, respectively), ${ }^{[5 b]}$ it is still feasible at room temperature through population of the upper vibrational states. In view of the thermodynamics, the process would be uphill and therefore expectedly slow allowing for alternative pathways such as the abovementioned Paternò-Büchi reaction to give oxetanes. This reaction requires a $n \pi^{\star}$ electronic configuration of the excited state, a requirement that is fulfilled in the case of BP.

In fact, previous studies have demonstrated that in solution ${ }^{3} \mathrm{BP}$ * is efficiently quenched by Thy derivatives $\left(k_{q}\right.$ in the range of $10^{8}$ $\left.10^{9} \mathrm{M}^{-1} \mathrm{~s}^{-1}\right) \cdot{ }^{[7 \mathrm{a}, \text { 9] }}$ Since the expected rate constant for TTET in solution is at least one order of magnitude lower (according to Sandros equation), formation of oxetanes essentially accounts for the determined quenching rate constant. The intramolecular version of this reaction has also been investigated, attaching directly one molecule of the chromophore to the sugar moiety of thymidine (Thd). Irradiation of the dyad leads to a mixture of photoproducts, in which the oxetanes are the major ones. ${ }^{[10]}$

A simplified mechanistic explanation of the reaction between ${ }^{3} \mathrm{BP}$ * and Thy is summarized in equations (1)-(3): $:^{[11]}$

Interestingly, irradiation of BP in the presence of Thy derivatives (2:1 ratio) gives mainly oxetanes, while dimers predominate in the presence of large excess of Thy. ${ }^{77 a}$, 9b] Although formation of dimers should be dependent on Thy concentration according to process (2), the observed changes in the oxetane to dimer ratio are clearly more marked than expected from kinetic analysis. Moreover, the unambiguous detection of cytosine dimers (Cyt<>Cyt) in photosensitized DNA (in spite of the high triplet energy of Cyt, ca. $\left.77 \mathrm{kcal} \mathrm{mol}^{-1}\right)^{[12]}$ suggests that formation of locally excited pyrimidine triplet states may not be the only mechanism of dimerization and that cooperative excited states may play a significant role. ${ }^{[13]}$ In this context, excited termolecular complexes (triplexes) have previously been proposed to explain the results obtained upon photosensitization of some [4+2] and $[2+2]$ cycloadditions. ${ }^{[14]}$ Although the involvement of triplet triplexes or, in general, delocalized triplet excited states has never been proven in the case of DNA, they could account for most of the experimental observations on the BP-photosensitized pyrimidine dimerization. This novel hypothesis is illustrated in equations (4) to (7):

Thus, quenching of ${ }^{3} \mathrm{BP}^{*}$ by Thy would lead to oxetanes via triplet exciplexes, while interaction of the latter with a second Thy unit would afford triplet triplexes, the immediate precursors of Thy $<>$ Thy.

In order to provide experimental evidence supporting the proposed mechanism, two Thy units have been now tethered to an appropriate bile acid scaffold. For this purpose, deoxycholic acid (DCA) (Scheme 1) has been selected as an appropriate skeleton, since it offers a rigid structure with two hydroxyl groups on the same face of the molecule allowing covalent attachment of the Thy bases. Linking of the carboxylic acid of the lateral chain with a BP moiety would lead to a fully intramolecular system where binary BP/Thy and Thy/Thy interactions (required in the currently accepted mechanism) are possible; by contrast, ternary BP/Thy/Thy interactions (involved in the novel proposal) would be prevented due to geometrical strain. Conversely, increasing the degrees of freedom by replacement of the 
intramolecular with an intermolecular BP chromophore should allow assembling a reactive triplet triplex, providing an experimental proof of the concept.

\section{Results and Discussion}

Two analogs have been synthesized using the skeleton of DCA (see Scheme 1). In the first one the two Thy units were covalently attached at positions $3 \alpha-$ and $12 \alpha-$ and the BP chromophore was esterified at the lateral chain, while in the second analog, BP was replaced with a benzyl group, which does not absorb in the UVA. Briefly, the developed synthetic strategy outlined in Scheme 1 started with the esterification of the carboxylic acid moiety of DCA with the $(S)$-enantiomer of reduced ketoprofen $(\mathrm{KP}-\mathrm{OH})$ to give DCAKP. Then, in the presence of an excess of Thy $-\mathrm{CH}_{2} \mathrm{CO}_{2} \mathrm{H}$, the two hydroxyl groups at $3 \alpha$ - plus $12 \alpha$ - were simultaneously esterified providing $1(3 \alpha, 12 \alpha-2$ Thy-DCAKP). To prepare the derivative without the BP unit, the carboxylic group at the lateral chain of DCA was reacted with benzyl bromide, giving DCABn. Subsequent treatment with Thy- $\mathrm{CH}_{2} \mathrm{CO}_{2} \mathrm{H}$ yielded 2 (3a,7a-2ThyDCABn).

Laser flash photolysis (LFP) was employed to monitor the triplet state obtained upon $355 \mathrm{~nm}$ excitation of the BP chromophore in the presence of two Thy units in the following systems: i) the fully intramolecular 1 and ii) the intermolecular 1:1 mixture of the parent BP and the non-absorbing 2.

Thus, the triplet of 1 was monitored at $520 \mathrm{~nm}$ (Figure 1 top) and compared to that of DCAKP, as a reference compound with the BP bound to the bile acid, but lacking the two Thy units. In this way, intramolecular hydrogen atom abstraction, a known deactivation pathway for ${ }^{3} \mathrm{BP}^{*}$ was also considered. Decays were fitted to a first order exponential equation and their lifetimes $(\tau)$ were 0.08 and $1.01 \mu \mathrm{s}$, respectively. More accurate determination was achieved by means of energy transfer to naphthalene $(\mathrm{NPH})^{[15]}$ (Figure 1 top, inset), which led to a value of $0.097 \mu \mathrm{s}$. This indicates a fast intramolecular deactivation of the triplet, with a rate constant of $9.3 \times 10^{6} \mathrm{~s}^{-1}(k=1 /$ T3a,12a-2Thy-DCAKP $-1 /$ TDCAKP $)$.

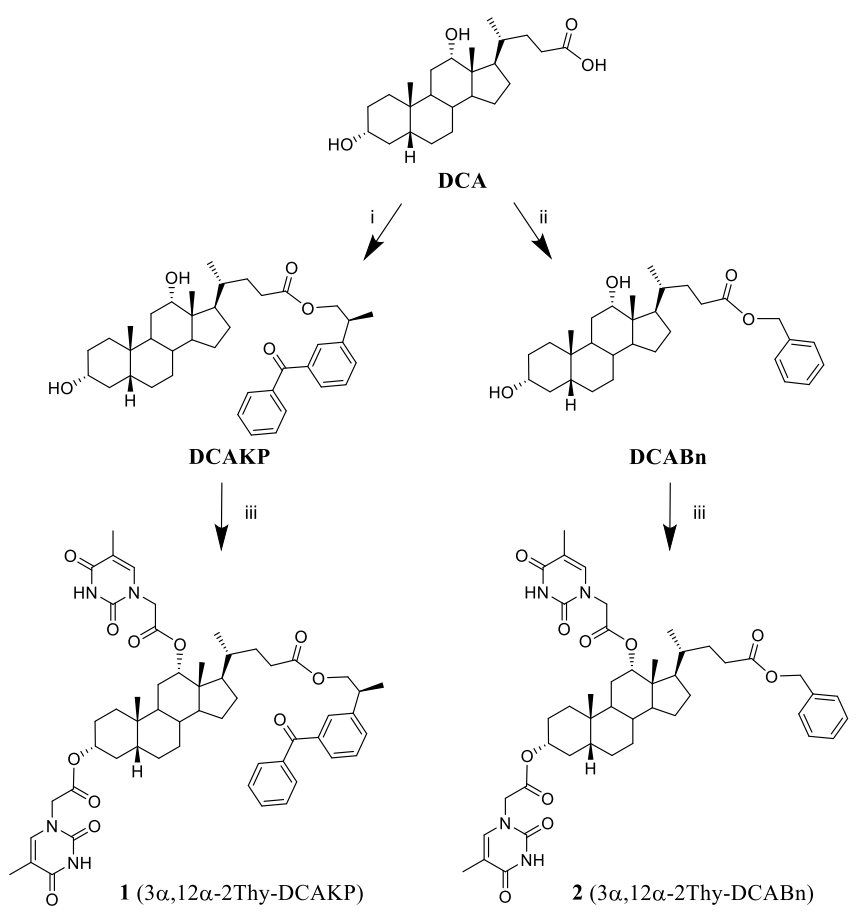

Scheme 1. Developed synthetic strategy to prepare DCA derivatives incorporating $\mathrm{BP}$ or $\mathrm{Bn}$ at the lateral chain and two Thy units. Reagents and conditions: (i) $\mathrm{KP}-\mathrm{OH}, 4-\mathrm{DMAP}, \mathrm{EDC}$, pyridine; (ii) benzyl bromide, DBU, DMF; (iii) Thy- $\mathrm{CH}_{2} \mathrm{COOH}$, Et3N, 2,4,6-trichlorobenzoyl chloride, 4-DMAP, THF.

Then, the lifetime of ${ }^{3} \mathrm{BP}^{*}$ was monitored upon addition of increasing concentrations of 2 (Figure 1 bottom). Stern-Volmer plots of the reciprocal lifetimes obtained in each case allowed determining the quenching rate constant, which was found to be $3.7 \times 10^{8} \mathrm{M}^{-1} \mathrm{~s}^{-1}$. For comparison, quenching of ${ }^{3} \mathrm{BP}^{*}$ by Thy occurred with $k=1.4 \times 10^{8} \mathrm{M}^{-1} \mathrm{~s}^{-1}$, which is reasonably similar when considering the 2 units of Thy per molecule in the case of 2.
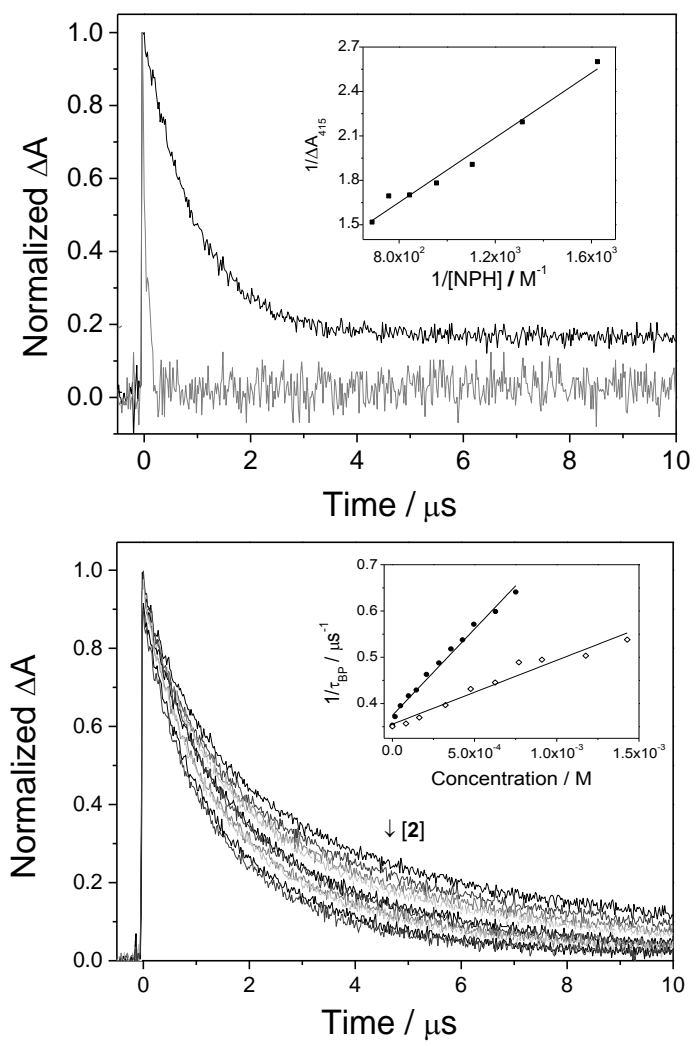

Figure 1. Top: LFP decays monitored at $520 \mathrm{~nm}$ of DCAKP (black) and $\mathbf{1}$ (gray) in $4 \mathrm{CH}_{3} \mathrm{CN}: 1 \mathrm{H}_{2} \mathrm{O}$. Inset: double reciprocal plot for energy transfer from 1 to $\mathrm{NPH}$, revealed through the absorption of ${ }^{3} \mathrm{NPH}^{*}$ at $415 \mathrm{~nm}$ immediately after the laser pulse. Bottom: LFP decays of BP monitored at $520 \mathrm{~nm}$ with increasing concentrations of $\mathbf{2}$. Inset: Stern-Volmer plot for the quenching of BP by $\mathbf{2}(\bullet)$ or by Thy $(\diamond)$.

A progressive decrease of the absorbance was observed in both systems, whereas the control mixture of BP:Thy (1:2 ratio) was almost unreactive (Figure 2, insets). Furthermore, when the residual UV spectra of $\mathbf{1}$ and $\mathrm{BP}: 2$ after reaction completion were compared to the hypothetical absorption due to unreacted BP or Thy (orange or blue traces, respectively, in Figure 2), a different reaction pattern was revealed. In fact, the UV of $\mathbf{1}$ at the end of the reaction was comparable to the one of Thy, pointing to the formation of an oxetane; conversely, the UV of the BP:2 system after irradiation resembled the one of $\mathrm{BP}$, thus indicating formation of Thy<> Thy. See also the difference upon zooming $300-400 \mathrm{~nm}$ in the insets of Figure 2 top and bottom. From the 
initial rates in the linear region, at less than $10 \%$ conversion, the reaction quantum yields for Thy<>Thy formation in BP:2 was ca. three times higher than that of 1BP:2Thy. Taking into account the reported data for the latter system, an upper limit for the value in the former would be $0.03 .{ }^{[5 \mathrm{c}]}$ Indeed, this was confirmed by analysis of the resulting photoproduct mixtures.

Thus, 1 was independently irradiated in acetonitrile under inert atmosphere, and the resulting crude product was purified by reverse-phase column chromatography. Only one photoproduct was obtained (Figure 3, left), whose structural characterization was achieved on the basis of ${ }^{1} \mathrm{H}$ and ${ }^{13} \mathrm{C}$ NMR spectroscopy, including ${ }^{13} \mathrm{C}$ DEPT-135, ${ }^{1} \mathrm{H}-{ }^{1} \mathrm{H}$ COSY and ${ }^{1} \mathrm{H}^{-13} \mathrm{C}$ HSQC

experiments, and also on exact mass determination. ${ }^{[10,16]}$ The photoproduct resulted to be one single oxetane derived from the Paternò-Büchi reaction between the KP moiety and the Thy unit at $12 \alpha$-. This was assessed by the appearance of a new singlet in the ${ }^{1} \mathrm{H}$ NMR at $4.72 \mathrm{ppm}$, concomitantly with the disappearance of one of the olefinic protons and with the upfield displacement of the aromatic signals. Furthermore, upon formation of the new ring the ${ }^{13} \mathrm{C}-\mathrm{NMR}$ signal corresponding to the original carbonyl group at $196.9 \mathrm{ppm}$ shifted to $91.7 \mathrm{ppm}$, in accordance with the values reported for analogous oxetanes. The regiochemistry assignment depicted in Figure 3 was based on the comparison of the chemical shifts of the two carbons formerly belonging to the Thy moiety with those found for related oxetanes. ${ }^{[6,9 a]}$ In fact, the obtained values of $\delta_{\mathrm{C}}=76.3 \mathrm{ppm}$ and $\delta_{\mathrm{CH}}=68.4 \mathrm{ppm}$ are in complete agreement with the expected values and far from those reported for the alternative regioisomers $\left(\delta_{\mathrm{C}}=52.7-57.8\right.$ and $\delta_{\mathrm{CH}}=80.0-90.0$ ppm).

Next, the intermolecular system BP:2 was irradiated in $\mathrm{CH}_{3} \mathrm{CN}$ under nitrogen. The main photoproduct was isolated by column chromatography (80\%) and was found to be trans-syn Thy<> Thy (Figure 3, right), whose structure was unambiguously established by crystal data (Figure 4).
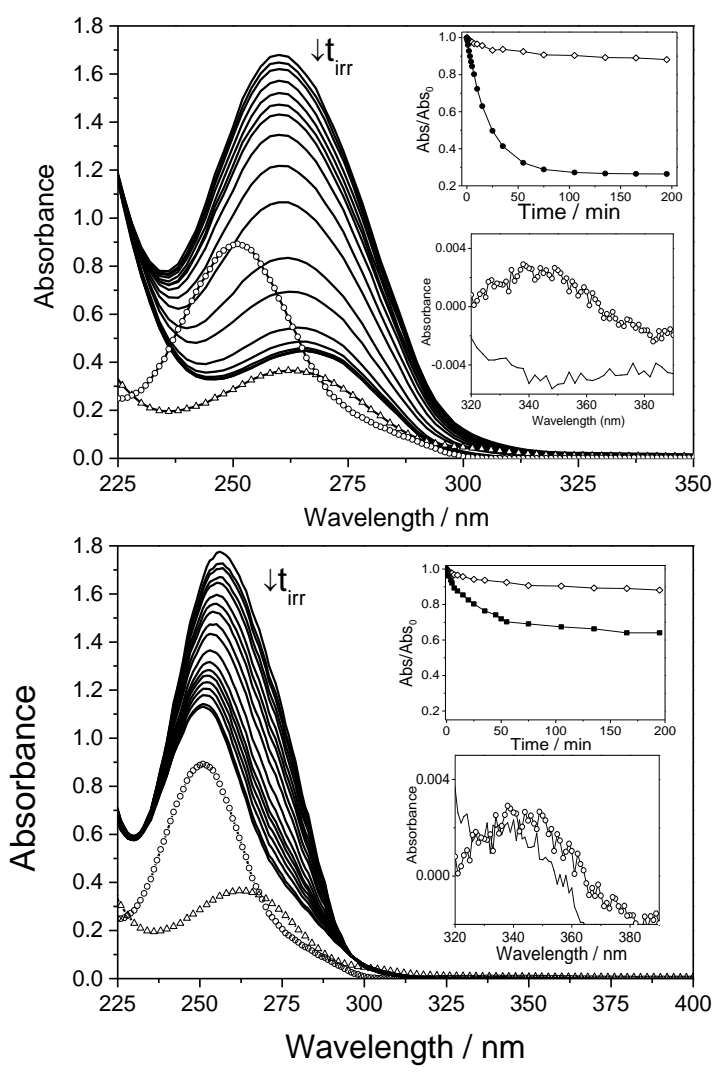

Figure 2. UV-Vis spectra of 1 (top) or BP:2 (bottom) monitored at different irradiation times $\left(\mathrm{C}_{\mathrm{i}}=4.4 \times 10^{-5} \mathrm{M}\right.$ in $4 \mathrm{CH}_{3} \mathrm{CN}: 1 \mathrm{H}_{2} \mathrm{O}$, inert atmosphere, $\lambda_{\max }=$ $350 \mathrm{~nm}$ ); UV spectra of BP $(\circ)$ and Thy $(\Delta)$ recorded at $4.4 \times 10^{-5} \mathrm{M}$. Upper insets: photoreaction kinetics of $\mathbf{1}(\bullet)$ or BP:2 (-) compared to 1BP:2Thy $(\diamond)$; Lower insets: zoom of 320-390 $\mathrm{nm}$ region after prolonged irradiation times of 1 or $\mathrm{BP}: 2$ compared to $\mathrm{BP}$ (ㅇ).
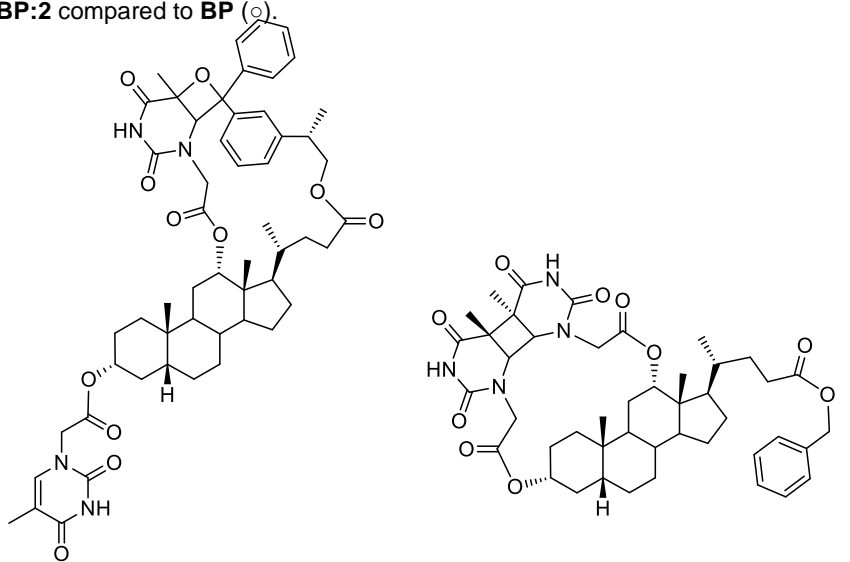

3 (3 $\alpha$-Thy-DCA- $12 \alpha$-Thy $<\mathrm{O}>\mathrm{KP})$

$4(3 \alpha, 12 \alpha-$ Thy $<>$ Thy-DCABn $)$

Figure 3. Photoproducts obtained upon irradiation of 1 (left) or BP:2 (right) in $\mathrm{CH}_{3} \mathrm{CN}$ under $\mathrm{N}_{2}$.

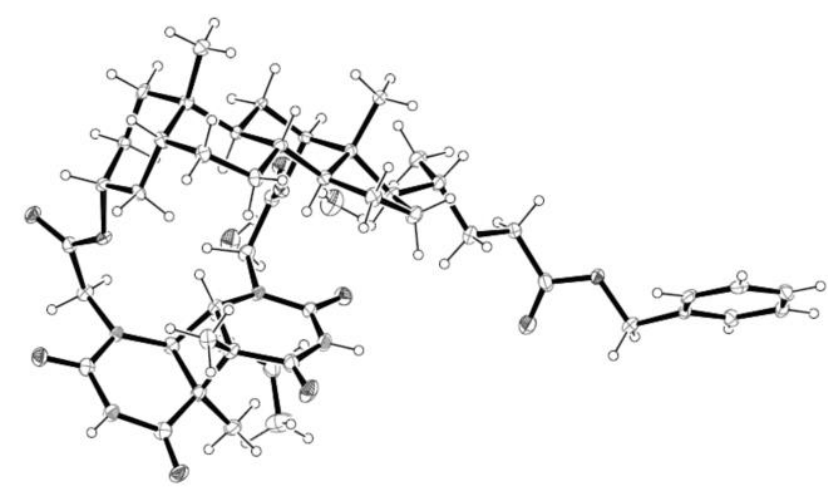

Figure 4. X-ray crystal structure of the Thy <>Thy (4) coming from the irradiation $\left(\lambda_{\max }=350 \mathrm{~nm}\right)$ of BP:2 in $\mathrm{CH}_{3} \mathrm{CN}$ under $\mathrm{N}_{2}$. CCDC: 1031373.

The obtained results revealed that the photochemical behavior of the inter- and intramolecular systems is dramatically diverging. In principle, the arrangement of the two Thy bases and a BP unit covalently attached to the same scaffold was expected to disfavor formation of Thy<> Thy in the triplex mechanism; in fact, the predominating process was by far production of an oxetane. This is clearly related to the evolution of the exciplexes depending on the degrees of freedom. In 1 the geometry of the ${ }^{3}[\mathrm{BP} \cdots$...Thy] exciplex is appropriate for production of the oxetane but not for triplex formation. By contrast, in the BP:2 mixture, the free arrangement of the ketone relative to the nucleobases allows assembling of the partners in the triplet triplex ${ }^{3}[\mathrm{BP} \cdots \text { Thy } \cdots \text { Thy }]^{*}$ with the appropriate geometry to afford Thy dimers as the final products. 


\section{Conclusions}

A new mechanistic pathway leading to photosensitized formation of cyclobutane pyrimidine dimers is proposed, in which the key step involves generation of a delocalized triplet excited state. The concept has been illustrated with systems combining one benzophenone (BP) and two thymine (Thy) units with different degrees of freedom where the photoreactivity can be switched from a clean Paternò-Büchi to a fully chemo-, regio- and stereoselective [2+2] dimerization. This finding underlines the importance of cooperative triplet excited states in DNA photodamage. Such delocalized chemical entities may predominate over locally excited triplet states when the thermodynamic requirement for energy transfer is not fulfilled.

\section{Experimental Section}

Additional experimental procedures, spectra of the new compounds and details about steady state and laser flash photolysis experiments are given in the Supporting Information (19 pages).

\section{Synthesis of (S)-KP-OH}

To a stirred solution of $(S)$-ketoprofen $(1.400 \mathrm{~g}, 5.50 \mathrm{mmol})$ in anhydrous THF $(14 \mathrm{~mL})$ at $-20{ }^{\circ} \mathrm{C}$, borane-tetrahydrofuran complex $(6.600 \mathrm{~mL}$ of a $1 \mathrm{M}$ solution, $6.60 \mathrm{mmol})$ was added dropwise, and the reaction mixture was allowed to warm overnight until room temperature. Then, the solution was cooled down again to $5{ }^{\circ} \mathrm{C}$ and treated with a $\mathrm{MeOH}: \mathrm{H}_{2} \mathrm{O}$ mixture $(15: 85,17 \mathrm{~mL})$. Afterwards, the solvents were concentrated in vacuum, the crude was redissolved in $\mathrm{CH}_{2} \mathrm{Cl}_{2}$ and poured into brine, extracted with $\mathrm{CH}_{2} \mathrm{Cl}_{2}$, washed with $\mathrm{NaHCO}_{3}(5 \%)$, dried over $\mathrm{MgSO}_{4}$ and evaporated under reduced pressure. Purification of the crude by column chromatography $\left(\mathrm{SiO}_{2}, \mathrm{CH}_{2} \mathrm{Cl}_{2}: \mathrm{MeOH}, 95: 5\right)$ gave the (S)enantiomer (KP-OH) as an oil $(0.728 \mathrm{~g}, 55 \%) .{ }^{1} \mathrm{H} \mathrm{NMR}(300 \mathrm{MHz}$, $\left.\mathrm{CDCl}_{3}\right): \delta$ (ppm) 1.31 (d, $\left.J=7.2 \mathrm{~Hz}, 3 \mathrm{H}, \mathrm{CH}_{3}\right) ; 1.49($ br s, $1 \mathrm{H}, \mathrm{OH})$; $3.04(\mathrm{~m}, 1 \mathrm{H}, \mathrm{CH}) ; 3.75\left(\mathrm{~m}, 2 \mathrm{H}, \mathrm{CH}_{2}\right) ; 7.40-7.84\left(\mathrm{~m}, 9 \mathrm{H}\right.$, arom). ${ }^{13} \mathrm{C}$ $\operatorname{NMR}\left(75 \mathrm{MHz}, \mathrm{CDCl}_{3}\right)$ : $\delta(\mathrm{ppm}) 197.0(\mathrm{C}), 144.5(\mathrm{C}), 137.7$ (C), $137.6(\mathrm{C}), 132.5(\mathrm{CH}), 131.8(\mathrm{CH}), 130.1(2 \times \mathrm{CH}), 128.9(\mathrm{CH})$, $128.5(\mathrm{CH}), 128.4(\mathrm{CH}), 128.3(2 \times \mathrm{CH}), 68.3\left(\mathrm{CH}_{2}\right), 42.3(\mathrm{CH})$, 17.6 $\left(\mathrm{CH}_{3}\right)$. MS: $\mathrm{m} / \mathrm{z}$ found 241.1219, calculated for $\mathrm{C}_{16} \mathrm{H}_{17} \mathrm{O}_{2}$ $\left(\mathrm{MH}^{+}\right) 241.1229$.

\section{Synthesis of DCAKP}

To a stirred mixture of DCA (0.772 g, $1.97 \mathrm{mmol}), \mathbf{K P}-\mathbf{O H}(0.394$ $\mathrm{g}, 1.64 \mathrm{mmol})$ and 4-DMAP $(0.200 \mathrm{~g}, 1.64 \mathrm{mmol})$ in anhydrous pyridine $(8 \mathrm{~mL})$ at $0{ }^{\circ} \mathrm{C}, \mathrm{EDC}(0.348 \mathrm{~mL}, 1.97 \mathrm{mmol})$ was added dropwise and the reaction mixture was allowed to react for one hour at $0{ }^{\circ} \mathrm{C}$ and then overnight at room temperature. Afterwards, the suspension was poured into $\mathrm{HCl} 1 \mathrm{M}$ and extracted with $\mathrm{CH} 2 \mathrm{Cl}$; the combined organic layers were washed with brine, dried over $\mathrm{MgSO} 4$ and concentrated under reduced pressure. Purification by column chromatography $\left(\mathrm{SiO}_{2}\right.$, AcOEt:hexane, 60:40) gave DCAKP as a colorless solid (0.666 g, 55\%). $1 \mathrm{H} \mathrm{NMR}$ (300 MHz, $\left.\mathrm{CDCl}_{3}\right): \delta$ (ppm) 0.64 (s, 3H, CH3); 0.90 (s, 3H, $\left.\mathrm{CH}_{3}\right)$; $0.92\left(\mathrm{~d}, \mathrm{~J}=6.3 \mathrm{~Hz}, 3 \mathrm{H}, 21-\mathrm{CH}_{3}\right) ; 1.33\left(\mathrm{~d}, \mathrm{~J}=7.2 \mathrm{~Hz}, 3 \mathrm{H}, \mathrm{KP}-\mathrm{CH}_{3}\right)$; $3.17(\mathrm{~m}, 1 \mathrm{H}, \mathrm{KP}-\mathrm{CH}) ; 3.61(\mathrm{~m}, 1 \mathrm{H}, 3 \beta-\mathrm{H}) ; 3.95$ (br s, $1 \mathrm{H}, 12 \beta-\mathrm{H})$; $4.16\left(\mathrm{dd}, \mathrm{J}=10.8\right.$ and $\left.6.6 \mathrm{~Hz}, 1 \mathrm{H}, \mathrm{KP}-\mathrm{CH}_{2}\right) ; 4.21$ (dd, $\mathrm{J}=10.8$ and $7.2 \mathrm{~Hz}, 1 \mathrm{H}, \mathrm{KP}-\mathrm{CH} 2) ; 7.39-7.82(\mathrm{~m}, 9 \mathrm{H}$, arom). 13C NMR (75 $\left.\mathrm{MHz}, \mathrm{CDCl}_{3}\right): \delta(\mathrm{ppm}) 196.9(\mathrm{C}), 174.2(\mathrm{C}), 143.8(\mathrm{C}), 137.9(\mathrm{C})$, $137.7(\mathrm{C}), 132.6(\mathrm{CH}), 131.5(\mathrm{CH}), 130.2(2 \times \mathrm{CH}), 129.1(\mathrm{CH})$, $128.8(\mathrm{CH}), 128.5(\mathrm{CH}), 128.4(2 \times \mathrm{CH}), 73.2(\mathrm{CH}), 72.0(\mathrm{CH}), 69.0$
$\left(\mathrm{CH}_{2}\right), 48.4(\mathrm{CH}), 47.4(\mathrm{CH}), 46.6(\mathrm{C}), 42.2(\mathrm{CH}), 39.0(\mathrm{CH}), 36.6$ $\left(\mathrm{CH}_{2}\right), 36.2(\mathrm{CH}), 35.3(\mathrm{CH} 2), 35.2(\mathrm{CH}), 34.2(\mathrm{C}), 33.8(\mathrm{CH}), 31.4$ $\left(\mathrm{CH}_{2}\right), 31.0(\mathrm{CH} 2), 30.7\left(\mathrm{CH}_{2}\right), 28.8\left(\mathrm{CH}_{2}\right), 27.5\left(\mathrm{CH}_{2}\right), 27.3\left(\mathrm{CH}_{2}\right)$, $26.3\left(\mathrm{CH}_{2}\right), 23.8\left(\mathrm{CH}_{2}\right), 23.3(\mathrm{CH} 3), 18.1\left(\mathrm{CH}_{3}\right), 17.4\left(\mathrm{CH}_{3}\right), 12.9$ $\left(\mathrm{CH}_{3}\right)$. MS: $\mathrm{m} / \mathrm{z}$ found 615.4038 , calculated for $\mathrm{C} 40 \mathrm{H} 55 \mathrm{O} 5\left(\mathrm{MH}^{+}\right)$ 615.4050 .

\section{Synthesis of $1(3 \alpha, 12 \alpha-2$ Thy-DCAKP)}

A stirred suspension of Thy- $\mathrm{CH}_{2} \mathrm{COOH}(1.192 \mathrm{~g}, 6.47 \mathrm{mmol})$ in anhydrous THF (40 mL) was treated with $\mathrm{Et}_{3} \mathrm{~N}(1.810 \mathrm{~mL}, 12.99$ $\mathrm{mmol}$ ) and 2,4,6-trichlorobenzoyl chloride (1.230 $\mathrm{mL}, 7.85 \mathrm{mmol})$ and the resulting mixture was allowed to react for $1.5 \mathrm{~h}$. Then, a solution of 4-DMAP $(0.527 \mathrm{~g}, 1.32 \mathrm{mmol})$ and DCAKP $(0.663 \mathrm{~g}$, $1.08 \mathrm{mmol})$ in anhydrous THF $(25 \mathrm{~mL})$ was added and the resulting reaction mixture was stirred overnight. Afterwards, it was poured into $\mathrm{NaHCO}_{3}(5 \%)$, extracted with $\mathrm{CH}_{2} \mathrm{Cl}_{2}$ and the combined extracts were washed with brine, dried over $\mathrm{MgSO}_{4}$ and concentrated under vacuum. Purification by column chromatography $\left(\mathrm{SiO}_{2}, \mathrm{CH}_{2} \mathrm{Cl}_{2}: \mathrm{MeOH}, 97: 3\right.$, followed by $\mathrm{Li}$ Chroprep RP-18, $\left.\mathrm{CH}_{3} \mathrm{CN}: \mathrm{H}_{2} \mathrm{O}, 80: 20\right)$ gave 1 as a yellow solid (0.959 g, 94\%). ${ }^{1} \mathrm{H}$ NMR (300 MHz, $\left.\mathrm{CDCl}_{3}\right): \delta$ (ppm) 0.68 (s, 3H, $\left.\mathrm{CH}_{3}\right) ; 0.74\left(\mathrm{~d}, J=6.3 \mathrm{~Hz}, 3 \mathrm{H}, 21-\mathrm{CH}_{3}\right) ; 0.88\left(\mathrm{~s}, 3 \mathrm{H}, \mathrm{CH}_{3}\right) ; 1.33(\mathrm{~d}$, $\left.J=6.9 \mathrm{~Hz}, 3 \mathrm{H}, \mathrm{KP}-\mathrm{CH}_{3}\right) ; 1.89$ (brs, 3H, Thy $\left.-\mathrm{CH}_{3}\right) ; 1.90($ br s, $3 \mathrm{H}$, Thy- $\left.\mathrm{CH}_{3}\right) ; 3.17$ (m, $\left.1 \mathrm{H}, \mathrm{KP}-\mathrm{CH}\right) ; 4.17$ (d, J=6.9 Hz, 2H, KP-CH ${ }_{2}$; 4.41 (d, $J=17.1 \mathrm{~Hz}, 1 \mathrm{H}$, Thy- $\left.\mathrm{CH}_{2}\right) ; 4.45$ (br s, 2H, Thy- $\left.\mathrm{CH}_{2}\right) ; 4.58$ (d, $J=17.1 \mathrm{~Hz}, 1 \mathrm{H}$, Thy- $\left.\mathrm{CH}_{2}\right) ; 4.71(b r \mathrm{~s}, 1 \mathrm{H}, 3 \beta-\mathrm{H}) ; 5.12(b r \mathrm{~s}$, $1 \mathrm{H}, 12 \beta-\mathrm{H}) ; 6.97$ (br s, $1 \mathrm{H}$, Thy-CH); 7.11 (br s, $1 \mathrm{H}$, Thy-CH); 7.39-7.85 (m, 9H, arom). ${ }^{13} \mathrm{C}$ NMR (100 MHz, $\left.\mathrm{CDCl}_{3}\right): \delta(\mathrm{ppm})$ 196.9 (C), 174.1 (C), 167.2 (C), 166.8 (C), 164.7 (C), 164.3 (C), $151.6(\mathrm{C}), 150.9(\mathrm{C}), 143.8(\mathrm{C}), 140.9(\mathrm{CH}), 140.3(\mathrm{CH}), 137.8$ $(\mathrm{C}), 137.7(\mathrm{C}), 132.7(\mathrm{CH}), 131.5(\mathrm{CH}), 130.2(2 \times \mathrm{CH}), 129.2(\mathrm{CH})$, $128.9(\mathrm{CH}), 128.5(\mathrm{CH}), 128.4(2 \times \mathrm{CH}), 111.5(\mathrm{C}), 110.8(\mathrm{C}), 78.1$ $(\mathrm{CH}), 76.9(\mathrm{CH}), 69.1\left(\mathrm{CH}_{2}\right), 49.7\left(\mathrm{CH}_{2}\right), 49.5(\mathrm{CH}), 49.4\left(\mathrm{CH}_{2}\right)$, $47.6(\mathrm{CH}), 45.3(\mathrm{C}), 41.9(\mathrm{CH}), 39.1(\mathrm{CH}), 35.7(\mathrm{CH}), 34.8(\mathrm{CH})$, $34.7\left(\mathrm{CH}_{2}\right), 34.5(\mathrm{CH}), 34.2(\mathrm{C}), 32.1\left(\mathrm{CH}_{2}\right), 31.4\left(\mathrm{CH}_{2}\right), 31.0$ $\left(\mathrm{CH}_{2}\right), 27.5\left(\mathrm{CH}_{2}\right), 27.0\left(\mathrm{CH}_{2}\right), 26.1\left(\mathrm{CH}_{2}\right), 25.9\left(\mathrm{CH}_{2}\right), 25.6\left(\mathrm{CH}_{2}\right)$, $23.6\left(\mathrm{CH}_{2}\right), 23.1\left(\mathrm{CH}_{3}\right), 18.1\left(\mathrm{CH}_{3}\right), 17.8\left(\mathrm{CH}_{3}\right), 12.5\left(2 \mathrm{xCH}_{3}\right), 12.4$ $\left(\mathrm{CH}_{3}\right)$. MS: $\mathrm{m} / \mathrm{z}$ found 947.4810 , calculated for $\mathrm{C}_{54} \mathrm{H}_{67} \mathrm{~N}_{4} \mathrm{O}_{11}\left(\mathrm{MH}^{+}\right)$ 947.4807.

\section{Synthesis of DCABn}

A stirred solution of DCA $(2.510 \mathrm{~g}, 6.39 \mathrm{mmol})$ in anhydrous DMF $(8 \mathrm{~mL})$ was treated with $\mathrm{DBU}(1.060 \mathrm{~mL}, 7.19 \mathrm{mmol})$. Ten minutes later, benzyl bromide $(0.850 \mathrm{~mL}, 7.18 \mathrm{mmol})$ was added dropwise and the solution was allowed to react overnight at room temperature. Then, the solvent was evaporated and the crude was redissolved with $\mathrm{AcOEt}$, washed with $\mathrm{NaHCO}_{3}(5 \%), \mathrm{HCl} 1 \mathrm{M}$ and brine, dried over $\mathrm{MgSO}_{4}$ and concentrated under reduced pressure. Purification by column chromatography $\left(\mathrm{SiO}_{2}\right.$, AcOEt:hexane, 90:10) gave DCABn as a colorless solid $(1.770 \mathrm{~g}$, $57 \%) .{ }^{1} \mathrm{H}$ NMR $\left(300 \mathrm{MHz}, \mathrm{CDCl}_{3}\right)$ : $\delta(\mathrm{ppm}) 0.64\left(\mathrm{~s}, 3 \mathrm{H}, \mathrm{CH}_{3}\right) ; 0.90$ (s, $\left.3 \mathrm{H}, \mathrm{CH}_{3}\right) ; 0.95\left(\mathrm{~d}, J=6.0 \mathrm{~Hz}, 3 \mathrm{H}, 21-\mathrm{CH}_{3}\right) ; 3.60(\mathrm{~m}, 1 \mathrm{H}, 3 \beta-$ $\mathrm{H}) ; 3.95$ (br s, $1 \mathrm{H}, 12 \beta-\mathrm{H})$ ); $5.08\left(\mathrm{~d}, J=12.3 \mathrm{~Hz}, 1 \mathrm{H}, \mathrm{CH}_{2}\right) ; 5.13$ (d, $\left.J=12.3 \mathrm{~Hz}, 1 \mathrm{H}, \mathrm{CH}_{2}\right) ; 7.38-7.28\left(\mathrm{~m}, 5 \mathrm{H}\right.$, arom). ${ }^{13} \mathrm{C}$ NMR $(75$ $\left.\mathrm{MHz}, \mathrm{CDCl}_{3}\right)$ : $\delta$ (ppm) $174.1(\mathrm{C}), 136.2(\mathrm{C}), 128.7(2 \times \mathrm{CH}), 128.4$ $(2 \times C H), 128.3(\mathrm{CH}), 73.2(\mathrm{CH}), 71.9(\mathrm{CH}), 66.2\left(\mathrm{CH}_{2}\right), 48.4(\mathrm{CH})$, $47.4(\mathrm{CH}), 46.6(\mathrm{C}), 42.2(\mathrm{CH}), 36.6\left(\mathrm{CH}_{2}\right), 36.1(\mathrm{CH}), 35.3\left(\mathrm{CH}_{2}\right)$, $35.2(\mathrm{CH}), 34.2(\mathrm{C}), 33.8(\mathrm{CH}), 31.5\left(\mathrm{CH}_{2}\right), 31.0\left(\mathrm{CH}_{2}\right), 30.6\left(\mathrm{CH}_{2}\right)$, $28.8\left(\mathrm{CH}_{2}\right), 27.6\left(\mathrm{CH}_{2}\right), 27.3\left(\mathrm{CH}_{2}\right), 26.2\left(\mathrm{CH}_{2}\right), 23.8\left(\mathrm{CH}_{2}\right), 23.3$ $\left(\mathrm{CH}_{3}\right), 17.4\left(\mathrm{CH}_{3}\right), 12.8\left(\mathrm{CH}_{3}\right) . \mathrm{MS}: \mathrm{m} / \mathrm{z}$ found 483.3480, calculated for $\mathrm{C}_{31} \mathrm{H}_{47} \mathrm{O}_{4}\left(\mathrm{MH}^{+}\right)$483.3474. 


\section{Synthesis of $2(3 \alpha, 12 \alpha-2$ Thy-DCABn)}

A stirred suspension of Thy- $\mathrm{CH}_{2} \mathrm{COOH}(1.720 \mathrm{~g}, 9.36 \mathrm{mmol})$ in anhydrous THF $(60 \mathrm{~mL})$ was treated with $\mathrm{Et}_{3} \mathrm{~N}(2.620 \mathrm{~mL}, 18.80$ $\mathrm{mmol})$ and 2,4,6-trichlorobenzoyl chloride $(1.750 \mathrm{~mL}, 11.23$ $\mathrm{mmol}$ ) and the resulting mixture was allowed to react for $1.5 \mathrm{~h}$. Then a solution of 4-DMAP $(0.232 \mathrm{~g}, 1.91 \mathrm{mmol})$ and DCABn $(0.752 \mathrm{~g}, 1.56 \mathrm{mmol})$ in anhydrous THF $(25 \mathrm{~mL})$ was added and stirred overnight. Afterwards, the reaction mixture was poured into $\mathrm{NaHCO}_{3}(5 \%)$, extracted with $\mathrm{CH}_{2} \mathrm{Cl}_{2}$ and the combined extracts were washed with brine, dried over $\mathrm{MgSO}_{4}$ and concentrated under vacuum. Purification by column chromatography $\left(\mathrm{SiO}_{2}\right.$, $\mathrm{CH}_{2} \mathrm{Cl}_{2}: \mathrm{MeOH}$, 98:2) and (Li Chroprep RP-18, $\mathrm{CH}_{3} \mathrm{CN}: \mathrm{H}_{2} \mathrm{O}$, $80: 20)$, gave 2 as a white solid (1.210 g, 95\%). ${ }^{1} \mathrm{H}$ NMR $(300 \mathrm{MHz}$, $\left.\mathrm{CDCl}_{3}\right): \delta(\mathrm{ppm}) 0.65\left(\mathrm{~s}, 3 \mathrm{H}, \mathrm{CH}_{3}\right) ; 0.77(\mathrm{~d}, J=5.7 \mathrm{~Hz}, 3 \mathrm{H}, 21-$ $\left.\mathrm{CH}_{3}\right) ; 0.86\left(\mathrm{~s}, 3 \mathrm{H}, \mathrm{CH}_{3}\right) ; 1.87$ (br s, 3H, Thy $\left.-\mathrm{CH}_{3}\right) ; 1.89($ br s, $3 \mathrm{H}$, Thy- $\left.\mathrm{CH}_{3}\right) ; 4.38$ (d, $J=17.4 \mathrm{~Hz}, 1 \mathrm{H}$, Thy $\left.-\mathrm{CH}_{2}\right) ; 4.40$ (d, $J=17.4$ $\mathrm{Hz}, 1 \mathrm{H}$, Thy $\left.-\mathrm{CH}_{2}\right) ; 4.49\left(\mathrm{~d}, J=17.4 \mathrm{~Hz}, 1 \mathrm{H}\right.$, Thy- $\left.\mathrm{CH}_{2}\right) ; 4.57(\mathrm{~d}, J$ $=17.4 \mathrm{~Hz}, 1 \mathrm{H}$, Thy $\left.-\mathrm{CH}_{2}\right) ; 4.70(\mathrm{~m}, 1 \mathrm{H}, 3 \beta-\mathrm{H}) ; 5.08\left(\right.$ br s, $\left.2 \mathrm{H}, \mathrm{CH}_{2}\right)$; 5.11 (br s, $1 \mathrm{H}, 12 \beta-\mathrm{H}) ; 6.98$ (br s, $1 \mathrm{H}$, Thy- $\mathrm{CH}) ; 7.05($ br s, $1 \mathrm{H}$, Thy- $\mathrm{CH})$; 7.26-7.37 (m, 5H, arom); 10.12 (s, $1 \mathrm{H}$, Thy-NH); 10.21 (s, $1 \mathrm{H}$, Thy-NH). ${ }^{13} \mathrm{C}$ NMR $\left(75 \mathrm{MHz}, \mathrm{CDCl}_{3}\right): \delta$ (ppm) 174.0 (C), 167.3 (C), 166.7 (C), 164.7 (C), 164.6 (C), 151.5 (C), 150.9 (C), $140.8(\mathrm{CH}), 140.5(\mathrm{CH}), 136.0(\mathrm{C}), 128.6(2 \times \mathrm{CH}), 128.3(3 \times \mathrm{CH})$, $111.2(\mathrm{C}), 110.7(\mathrm{C}), 77.9(\mathrm{CH}), 76.5(\mathrm{CH}), 66.2\left(\mathrm{CH}_{2}\right), 49.3$ $\left(\mathrm{CH}+2 \times \mathrm{CH}_{2}\right), 47.5(\mathrm{CH}), 45.2(\mathrm{C}), 41.7(\mathrm{CH}), 35.5(\mathrm{CH}), 34.7$ $\left(\mathrm{CH}+\mathrm{CH}_{2}\right), 34.2(\mathrm{CH}), 34.1(\mathrm{C}), 31.9\left(\mathrm{CH}_{2}\right), 31.3\left(\mathrm{CH}_{2}\right), 30.8$ $\left(\mathrm{CH}_{2}\right), 27.3\left(\mathrm{CH}_{2}\right), 26.8\left(\mathrm{CH}_{2}\right), 26.0\left(\mathrm{CH}_{2}\right), 25.9\left(\mathrm{CH}_{2}\right), 25.3\left(\mathrm{CH}_{2}\right)$, $23.4\left(\mathrm{CH}_{2}\right), 22.9\left(\mathrm{CH}_{3}\right), 17.7\left(\mathrm{CH}_{3}\right), 12.4\left(2 \times \mathrm{CH}_{3}\right), 12.2\left(\mathrm{CH}_{3}\right) . \mathrm{MS}$ : $\mathrm{m} / \mathrm{z}$ found 815.4200 , calculated for $\mathrm{C}_{45} \mathrm{H}_{59} \mathrm{~N}_{4} \mathrm{O}_{10}\left(\mathrm{MH}^{+}\right) 815.4231$.

\section{Irradiation of 1}

A solution of $1(0.148 \mathrm{~g}, 0.16 \mathrm{mmol})$ in $\mathrm{CH}_{3} \mathrm{CN}(250 \mathrm{~mL})$, placed in a Pyrex® round-bottom flask was purged with $\mathrm{N}_{2}$ and irradiated in a photoreactor using 8 lamps $\left(\lambda_{\max }=350 \mathrm{~nm}\right)$ for two hours. Then, the solvent was concentrated under vacuum and the crude was purified by column chromatography $\left(\mathrm{SiO}_{2}, \mathrm{CH}_{2} \mathrm{Cl}_{2}: \mathrm{MeOH}\right.$, 99:1) and (Li Chroprep RP-18, $\mathrm{CH}_{3} \mathrm{CN}: \mathrm{H}_{2} \mathrm{O}, 80: 20$ ) to give 3 (3aThy-DCA-12a-Thy<O>KP) (0.095 g, 64\%). ${ }^{1} \mathrm{H}$ NMR $(300 \mathrm{MHz}$, $\left.\mathrm{CDCl}_{3}\right): \delta(\mathrm{ppm}) 0.75\left(\mathrm{~s}, 3 \mathrm{H}, \mathrm{CH}_{3}\right) ; 0.86\left(\mathrm{~m}, 6 \mathrm{H}, \mathrm{CH}_{3}+21-\mathrm{CH}_{3}\right)$; 1.35 (d, $\left.J=7.2 \mathrm{~Hz}, 3 \mathrm{H}, \mathrm{KP}-\mathrm{CH}_{3}\right) ; 1.82\left(\right.$ br s, $\left.3 \mathrm{H}, \mathrm{Thy}-\mathrm{CH}_{3}\right) ; 1.92$ (br s, 3H, Thy- $\left.\mathrm{CH}_{3}\right) ; 2.23\left(\mathrm{~m}, 2 \mathrm{H}, \mathrm{CH}_{2}\right) ; 3.10(\mathrm{~m}, 1 \mathrm{H}, \mathrm{KP}-\mathrm{CH}) ; 3.57$ (d, $J=17.7 \mathrm{~Hz}, 1 \mathrm{H}$, Thy-CH $)_{2}$; 4.02 (t, $J=10.5 \mathrm{~Hz}, 1 \mathrm{H}, \mathrm{KP}-\mathrm{CH}_{2}$ ); $4.21\left(\mathrm{~d}, J=17.1 \mathrm{~Hz}, 1 \mathrm{H}\right.$, Thy- $\left.\mathrm{CH}_{2}\right) ; 4.51(\mathrm{~d}, J=17.1 \mathrm{~Hz}, 1 \mathrm{H}$, Thy$\mathrm{CH}_{2}$ ); 4.53 (dd, $J=3.9$ and $\left.10.5 \mathrm{~Hz}, 1 \mathrm{H}, \mathrm{KP}-\mathrm{CH}_{2}\right) ; 4.61(\mathrm{~m}, 1 \mathrm{H}$, $3 \beta-\mathrm{H}) ; 4.62\left(\mathrm{~d}, J=17.7 \mathrm{~Hz}, 1 \mathrm{H}\right.$, Thy- $\left.\mathrm{CH}_{2}\right) ; 4.72(\mathrm{brs}, 1 \mathrm{H}$, oxetane$\mathrm{CH}) ; 5.27(\mathrm{~s}, 1 \mathrm{H}, 12 \beta-\mathrm{H}) ; 6.91(\mathrm{~s}, 1 \mathrm{H}, \mathrm{Thy}-\mathrm{CH}) ; 7.10-7.46(\mathrm{~m}, 9 \mathrm{H}$, arom); 8.96 (s, 1H, Thy-NH); 9.38 (s, 1H, Thy-NH). ${ }^{13} \mathrm{C}$ NMR $(75$ $\mathrm{MHz}, \mathrm{CDCl}_{3}$ ) $\delta(\mathrm{ppm}) 173.5(\mathrm{C}), 170.5(\mathrm{C}), 167.0$ (C), 166.7 (C), $164.0(\mathrm{C}), 151.6(\mathrm{C}), 150.7(\mathrm{C}), 144.3(\mathrm{C}), 143.3(\mathrm{C}), 140.0(\mathrm{CH})$, $138.2(\mathrm{C}), 129.6(\mathrm{CH}), 128.9(2 \times \mathrm{CH}), 128.8(\mathrm{CH}), 126.2(\mathrm{CH})$, $126.1(2 \times C H), 124.9(\mathrm{CH}), 124.6(\mathrm{CH}), 111.8(\mathrm{C}), 91.7(\mathrm{C}), 77.6$ $(\mathrm{CH}), 77.2(\mathrm{CH}), 76.3(\mathrm{C}), 69.1\left(\mathrm{CH}_{2}\right), 68.4(\mathrm{CH}), 50.1(\mathrm{CH}), 50.0$ $\left(\mathrm{CH}_{2}\right), 49.2\left(\mathrm{CH}_{2}\right), 47.7(\mathrm{CH}), 45.2(\mathrm{C}), 41.9(\mathrm{CH}), 39.8(\mathrm{CH}), 36.4$ $(\mathrm{CH}), 35.7(\mathrm{CH}), 35.1(\mathrm{CH}), 34.7\left(\mathrm{CH}_{2}\right), 34.5(\mathrm{C}), 32.2\left(\mathrm{CH}_{2}\right), 31.7$ $\left(\mathrm{CH}_{2}\right), 30.0\left(\mathrm{CH}_{2}\right), 28.0\left(\mathrm{CH}_{2}\right), 27.0\left(\mathrm{CH}_{2}\right), 26.2\left(\mathrm{CH}_{2}\right), 25.9\left(\mathrm{CH}_{2}\right)$, $25.7\left(\mathrm{CH}_{2}\right), 24.5\left(\mathrm{CH}_{3}\right), 23.5\left(\mathrm{CH}_{2}\right), 23.3\left(\mathrm{CH}_{3}\right), 17.9\left(\mathrm{CH}_{3}\right), 17.8$ $\left(\mathrm{CH}_{3}\right), 12.5\left(\mathrm{CH}_{3}\right), 12.4\left(\mathrm{CH}_{3}\right) . \mathrm{MS}: \mathrm{m} / \mathrm{z}$ found 947.4805, calculated for $\mathrm{C}_{54} \mathrm{H}_{67} \mathrm{~N}_{4} \mathrm{O}_{11}\left(\mathrm{MH}^{+}\right) 947.4807$.

\section{Irradiation of the mixture BP:2}

A solution of $2(0.102 \mathrm{~g}, 0.12 \mathrm{mmol})$ and $\mathbf{B P}(0.022 \mathrm{~g}, 0.12 \mathrm{mmol})$ in $\mathrm{CH}_{3} \mathrm{CN}(150 \mathrm{~mL})$, placed in a Pyrex® round-bottom flask was purged with $\mathrm{N}_{2}$ and irradiated in a photoreactor using 8 lamps $\left(\lambda_{\max }=350 \mathrm{~nm}\right)$ for six hours. Then, the solvent was concentrated under vacuum and the crude was purified by column chromatography $\left(\mathrm{SiO}_{2}, \mathrm{CH}_{2} \mathrm{Cl}_{2}\right.$ : Acetone, 90:10) to give 4 $\left(3 \alpha, 12 \alpha-T h y<>\right.$ Thy-DCABn) $(0.084 \mathrm{~g}, 82 \%) .{ }^{1} \mathrm{H}$ NMR $(300 \mathrm{MHz}$, $\left.\mathrm{CDCl}_{3}\right): \delta(\mathrm{ppm}) 0.70\left(\mathrm{~s}, 3 \mathrm{H}, \mathrm{CH}_{3}\right) ; 0.83(\mathrm{~d}, J=4.5 \mathrm{~Hz}, 3 \mathrm{H}, 21$ $\left.\mathrm{CH}_{3}\right) ; 0.88\left(\mathrm{~s}, 3 \mathrm{H}, \mathrm{CH}_{3}\right) ; 1.59\left(\mathrm{~s}, 3 \mathrm{H}\right.$, Thy- $\left.\mathrm{CH}_{3}\right) ; 1.68$ (s, 3H, Thy$\left.\mathrm{CH}_{3}\right)$; 3.40-3.56 (m, 2H, Thy- $\left.\mathrm{CH}_{2}\right)$; 3.60 (br s, $1 \mathrm{H}$, Thy $<>$ Thy- $\left.\mathrm{CH}\right)$; $4.16\left(\right.$ br s, $1 \mathrm{H}$, Thy<>Thy-CH); 4.35-4.56 (m, 2H, Thy- $\left.\mathrm{CH}_{2}\right) ; 4.92$ $(\mathrm{m}, 1 \mathrm{H}, 3 \beta-\mathrm{H}) ; 5.12\left(b r \mathrm{~s}, 3 \mathrm{H}, \mathrm{CH}_{2}+12 \beta-\mathrm{H}\right) ; 7.24-7.38(\mathrm{~m}, 5 \mathrm{H}$, arom); 8.40 (s, $1 \mathrm{H}$, Thy-NH); $8.58\left(\mathrm{~s}, 1 \mathrm{H}\right.$, Thy-NH). ${ }^{13} \mathrm{C}$ NMR $(75$ $\mathrm{MHz}, \mathrm{CDCl}_{3}$ ): $\delta$ (ppm) 174.3 (C), 168.4 (C), 168.2 (C), 166.6 (2xC), 150.5 (C), $150.4(\mathrm{C}), 136.0$ (C), $128.7(2 \times C H), 128.5$ $(2 \times C H), 128.3(\mathrm{CH}), 79.0(\mathrm{CH}), 74.1(\mathrm{CH}), 66.5\left(\mathrm{CH}_{2}\right), 63.6(\mathrm{CH})$, $52.5(\mathrm{CH}), 51.3\left(\mathrm{CH}_{2}\right), 49.4\left(\mathrm{CH}_{2}\right), 46.7(\mathrm{CH}), 45.3(2 \times \mathrm{C}), 45.0$ (C), $39.9(\mathrm{CH}), 34.9(\mathrm{CH}), 34.5(\mathrm{CH}), 34.0\left(\mathrm{CH}_{2}\right), 33.2(\mathrm{CH}), 32.4$ (C), $31.0(\mathrm{CH}), 30.6\left(\mathrm{CH}_{2}\right), 30.2\left(\mathrm{CH}_{2}\right), 29.6\left(\mathrm{CH}_{2}\right), 27.4\left(\mathrm{CH}_{2}\right)$, $25.7\left(\mathrm{CH}_{2}\right), 25.6\left(\mathrm{CH}_{2}\right), 25.1\left(\mathrm{CH}_{2}\right), 23.4\left(\mathrm{CH}_{2}\right), 23.1\left(\mathrm{CH}_{2}\right), 22.8$ $\left(\mathrm{CH}_{3}\right), 22.4\left(\mathrm{CH}_{3}\right), 21.5\left(\mathrm{CH}_{3}\right), 17.1\left(\mathrm{CH}_{3}\right), 12.5\left(\mathrm{CH}_{3}\right) . \mathrm{MS}: \mathrm{m} / \mathrm{z}$ found 815.4266, calculated for $\mathrm{C}_{45} \mathrm{H}_{59} \mathrm{~N}_{4} \mathrm{O}_{10}\left(\mathrm{MH}^{+}\right)$815.4231.

\section{Acknowledgements}

Financial support from the Spanish Government (Grants SEV2012-0267, CTQ2012-38754-C03-03 and CTQ2012-32621), Generalitat Valenciana (Prometeo Program) and Technical University of Valencia (Predoctoral FPI fellowship for P. Miro) is gratefully acknowledged.

Keywords: cyclobutane dimer $\cdot$ DNA damage $\bullet$ energy transfer laser flash photolysis $\bullet$ oxetane

[1] a) S. Mouret, C. Baudouin, M. Charveron, A. Favier, J. Cadet, T. Douki, Proc Natl. Acad. Sci. 2006, 103, 13765-13770; b) R. B. Setlow, E. Grist, K. Thompson, A. D. Woodhead, Proc. Natl. Acad. Sci. 1993, 90, 6666-6670; c) P. J. Rochette, J.-P. Therrien, R. Drouin, D. Perdiz, N. Bastien, E. A Drobetsky, E. Sage, Nucl. Acids Res. 2003, 31, 2786-2794.

[2] a) C. A. Smith, M. Wang, N. Jiang, L. Che, X. Zhao, J.-S. Taylor, Biochemistry 1996, 35, 4146-4154; b) A. Gentil, F. Le Page, A. Borden, A Sarasin, Nucl. Acids Res. 1996, 24, 1837-1840; c) K. Heil, D. Pearson, T. Carell, Chem. Soc. Rev. 2011, 40, 4271-4278.

[3] a) W. J. Schreier, T. E. Schrader, F. O. Koller, P. Gilch, C. E. CrespoHernandez, V. N. Swaminathan, T. Carell, W. Zinth, B. Kohler, Science 2007, $315,625-629$; b) B. M. Pilles, D. B. Bucher, L. Liu, P. Clivio, P. Gilch, W. Zinth, W. J. Schreier, J. Phys. Chem. Lett. 2014, 5, 1616-1622.

[4] T. Climent, I. Gonzalez-Ramirez, R. Gonzalez-Luque, M. Merchan, L. Serrano-Andres, J. Phys. Chem. Lett. 2010, 1, 2072-2076.

[5] a) T. Delatour, T. Douki, C. D'Ham, J. Cadet, J. Photochem. Photobiol., $B$ 1998, 44, 191-198; b) M. C. Cuquerella, V. Lhiaubet-Vallet, J. Cadet, M. A. Miranda, Acc. Chem. Res. 2012, 45, 1558-1570; c) M. C. Cuquerella, V. Lhiaubet-Vallet, F. Bosca, M. A. Miranda, Chem. Sci. 2011, 2, 1219-1232.

[6] S. L. Murov, I. Carmichael, G. L. Hug, 2nd ed. (Ed.: M. Dekker), New York, 2009.

[7] a) S. Encinas, N. Belmadoui, M. J. Climent, S. Gil, M. A. Miranda, Chem Res. Toxicol. 2004, 17, 857-862; b) J. Trzcionka, V. Lhiaubet-Vallet, C. Paris, N. Belmadoui, M. J. Climent, M. A. Miranda, ChemBioChem 2007, 8, 402 407; c) A. Joseph, G. Prakash, D. E. Falvey, J. Am. Chem. Soc. 2000, 122, 11219-11225.

[8] K. Sandros, Acta Chem. Scand. 1964, 18, 2355-\&.

[9] a) I. G. Gut, P. D. Wood, R. W. Redmond, J. Am. Chem. Soc. 1996, 118, 2366 2373; b) V. Lhiaubet-Vallet, S. Encinas, M. A. Miranda, J. Am. Chem. Soc 2005, 127, 12774-12775.

[10] N. Belmadoui, S. Encinas, M. J. Climent, S. Gil, M. A. Miranda, Chem. Eur J. 2006, 12, 553-561.

[11] X.-L. Liu, J.-B. Wang, Y. Tong, Q.-H. Song, Chem. Eur. J. 2013, 19, 13216 13223.

[12] P. D. Wood, R. W. Redmond, J. Am. Chem. Soc. 1996, 118, 4256-4263.

[13] T. Douki, I. Berard, A. Wack, S. Andrae, Chem. Eur. J. 2014, 20, 5787-5794.

[14] a) J. I. Kim, G. B. Schuster, J. Am. Chem. Soc. 1992, 114, 9309-9317; b) J. Pérez-Prieto, S.-E. Stiriba, M. González-Béjar, L. R. Domingo, M. A Miranda, Org. Lett. 2004, 6, 3905-3908; c) M. González-Béjar, A. Bentama, 
M. A. Miranda, S.-E. Stiriba, J. Pérez-Prieto, Org. Lett. 2007, 9, 2067-2070;

d) I. Wolfle, S. Chan, G. B. Schuster, J. Org. Chem. 1991, 56, 7313-7319.

[15] F. Bosca, I. Andreu, I. M. Morera, A. Sam

Commun. 2003, 1592-1593. 
